FLOOD TIME ARRIVAL ESTIMATION BASED ON EMPIRICAL ANALYSIS OF RECORDED DATA OF FLOOD EARLY WARNING SYSTEM IN BEKASI CITY

\title{
PERKIRAAN WAKTU KEDATANGAN BANJIR BERDASARKAN ANALISIS EMPIRIK REKAMAN DATA SISTEM PERINGATAN DINI BANJIR KOTA BEKASI
}

\author{
Prihartanto ${ }^{1}$ dan Deliyanti Ganesha ${ }^{1}$ \\ ${ }^{1}$ Pusat Teknologi Reduksi Risiko Bencana, Gedung 820 Teknologi Sistem Kebumian - BPPT \\ Phone:08159962260 e-mail: prihartanto@bppt.go.id
}

\begin{abstract}
Flood disaster that occured in the Kali Bekasi watershed often causing loss of property and casualties. The watershed is divided into two main parts namely upstream and downstream watersheds which are limited by Bekasi Dam. High rainfall in the upstream often causes flooding in Pondok Gede Permai Estate, Bekasi City. To improve community preparedness, a flood early warning system (FEWS) has been installed which consists of 5 monitoring stations along the Cileungsi and Cikeas Rivers in 2017. The main question that needs to be answered in this paper is how long the upstream flood peak will reach community settlements. Based on the recorded data on the FEWS instrument, the flood peak travel time from the upstream station to the affected area can be calculated empirically. The results of the time calculation can be used by stakeholders to carry out evacuation after an early warning is given. The parameter used in this analysis are the river water level at several monitoring stations on the Cileungsi River, namely: Cibongas Irrigation Dam, WIKA Bridge and Pondok Gede Permai.

Keywords: Flood, Kali Bekasi Watershed, Flood Early Warning System, Preparednes
\end{abstract}

\begin{abstract}
Abstrak
Bencana banjir yang terjadi di DAS Bekasi sering menimbulkan kerugian harta benda maupun korban jiwa. DAS ini terbagi atas dua bagian utama yaitu DAS dua bagian yaitu bagian hulu dan bagian hilir yang dibatasi oleh Bendung Bekasi. Curah hujan yang tinggi di DAS bagian hulu sering menimbulkan banjir di Perumahan Pondok Gede Permai, Kota Bekasi. Untuk meningkatkan kesiapsiagaan masyarakat di perumahan tersebut, maka telah dipasang sistem peringatan dini banjir (Flood Early Warning System/FEWS) yang terdiri dari 5 stasiun pemantauan di sepanjang Sungai Cileungsi dan Cikeas pada tahun 2017. Pertanyaan utama yang perlu dijawab dalam makalah ini adalah berapa lama puncak banjir di bagian hulu akan mencapai permukiman masyarakat. Berdasarkan basis data yang telah terekam pada instrumen FEWS tersebut, waktu perjalanan puncak banjir dari stasiun hulu menunju area terdampak dapat dihitung secara empirik. Hasil perhitungan waktu tersebut dapat dimanfaatkan oleh para pemangku kepentingan untuk melakukan evakuasi setelah peringatan dini diberikan. Parameter yang digunakan dalam analisis ini adalah tinggi muka air yang di beberapa stasiun pemantauan di Sungai Cileungsi yaitu : Dam Irigasi Cibongas, Jembatan WIKA dan Pondok Gede Permai.
\end{abstract}

Kata kunci: Banjir, DAS Kali Bekasi, Sistem Peringatan Dini Banjir, Kesiapsiagaan 


\section{PENDAHULUAN}

\subsection{Latar Belakang}

Banjir merupakan bencana alam yang paling sering terjadi di Indonesia yang dapat menimbulkan kerugian bahkan menelan korban jiwa. Penyebab banjir meliputi faktor iklim dan faktor fisik kawasan. Salah satu penyebab terjadinya banjir adalah curah hujan terus menerus yang melebihi daya tampung sungai, danau atau saluran drainase/selokan (Suparta, 2004). Sedangkan menurut UndangUndang Nomor 24 Tahun 2007 tentang Penanggulangan Bencana, bencana banjir adalah peristiwa atau keadaan dimana terendamnya suatu daerah atau daratan karena volume air yang meningkat.

Bekasi merupakan salah satu wilayah di Jawa Barat yang memiliki kerentanan terhadap banjir (Khairana, 2013). Kota Bekasi terletak pada tiga DAS utama yaitu DAS Bekasi $(9444,886 \mathrm{Ha})$, DAS Sunter $(3970,014$ $\mathrm{Ha})$ dan DAS Cakung $(7042,052 \mathrm{Ha})$ (Nurhayati, 2009). Salah satu DAS yang sering mengalami Banjir adalah DAS Bekasi yang terdiri dari sub DAS Cileungsi dan sub DAS Cikeas.

DAS Bekasi terbagi dua bagian yaitu DAS Bekasi Hulu dan Hilir dan dibatasi oleh Bendung Bekasi sebagaimana diperlihatkan pada Gambar 1.

Secara administrasi DAS Bekasi Hulu terletak di Kabupaten Bogor, Kabupaten Bekasi, dan Kota Bekasi, Provinsi Jawa Barat. Koordinat geografis DAS Bekasi Hulu terletak pada $106^{\circ} 49^{\prime} 05^{\prime \prime}-107^{\circ} 01^{\prime} 47^{\prime \prime}$ Bujur Timur, 06 $14^{\prime} 09^{\prime \prime}-06^{\circ} 42^{\prime 2} 1^{\prime \prime}$ Lintang Selatan. Penentuan batas hilir dari DAS Bekasi Hulu didasarkan pada letak bendung Bekasi pada 106 ${ }^{\circ} 9^{\prime}$ 35" Bujur Timur, 06¹4' 09" Lintang Selatan yang memisahkan sistem tata air Sungai Bekasi Hulu dan Hilir (Kadri, 2011).

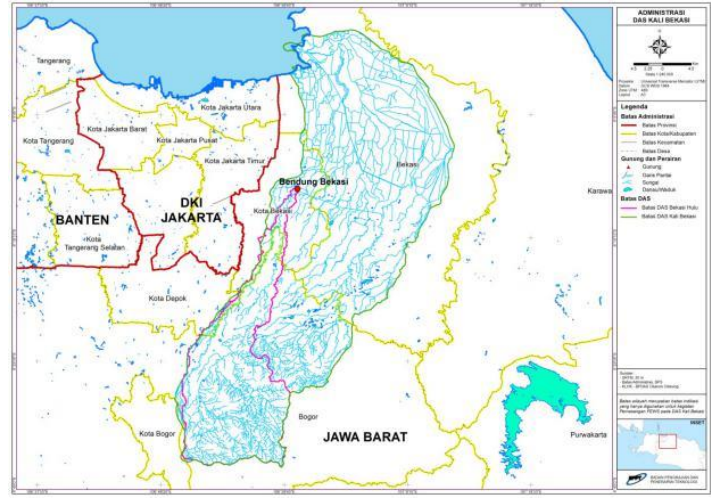

Gambar 1. Daerah Aliran Sungai (DAS) Bekasi

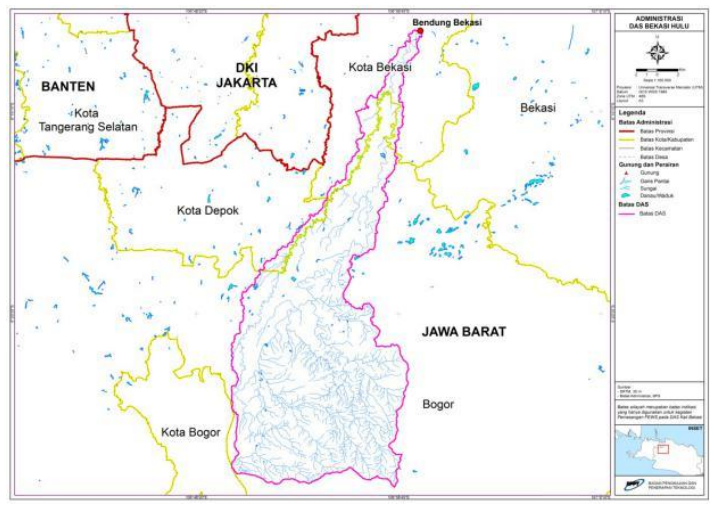

Gambar 2. DAS Bekasi di Bagian Hulu

Beberapa kecamatan dan kelurahan yang selama ini memiliki risiko tinggi terhadap terjadinya ancaman bencana banjir di Kota Bekasi (Bappeda, 2016) antara lain sebagai berikut:

a. Kecamatan Bekasi Utara, meliputi: Kelurahan Harapan Jaya;

b. Kecamatan Medansatria, meliputi: Kelurahan Pejuang, Medansatria, dan Kalibaru.

c. Kecamatan Jatiasih, meliputi: Kelurahan Jatikramat, Jatimekar, dan Jatisari;

d. Kecamatan Mustikajaya meliputi: Kelurahan Mustikajaya;

e. Kecamatan Bantargebang, meliputi: Kelurahan Cikiwul;

f. Kecamatan Pondok Melati, yaitu di Kelurahan Jatirahayu.

Banjir yang terjadi pada tanggal 21 Februari 2017 mencapai 79 titik banjir dan menimbulkan korban jiwa sebanyak dua orang serta $1.314 \mathrm{KK}$ terdampak banjir. Banjir 
tersebut disebabkan oleh meluapnya Sungai Cileungsi dan Cikeas yang merendam ribuan rumah di 24 kelurahan dari 10 kecamatan di Kota Bekasi (detik.com, 2017). Kedua sungai tersebut berada di DAS Bekasi bagian hulu. Salah satu perumahan yang terdampak akibat banjir tersebut adalah perumahan Pondok Gede Permai.

Banjir yang sering terjadi di sekitar perumahan Pondok Gede Permai selain diakibatkan oleh curah hujan yang tinggi, juga diakibatkan juga oleh lokasi perumahan ini yang berada di bantaran Kali Bekasi yang merupakan titik pertemuan antara Kali CikeasCileungsi di Kabupaten Bogor (Hikmah, 2016). Penyebab lain terjadinya banjir di Kota Bekasi adalah adalah perubahan penggunaan lahan di DAS Bekasi Hulu berupa peningkatan luasan permukiman dan penurunan luasan hutan (Kadri, 2011). Kejadian banjir yang terparah adalah yang terjadi pada tanggal 21 April 2016, dengan ketinggian banjir di pemukiman warga mencapai 3,5 - 4 meter. Sehingga menjadi salah satu alasan di pasangnya instrumen sistem peringatan dini di lokasi tersebut (Akhirianto, 2018).

Untuk menurunkan risiko akibat bencana banjir dengan meningkatkan kesiapsiagaan masyarakat di sekitar perumahan Pondok Gede Permai terhadap bencana banjir, maka pada tahun 2017 telah dibangun sistem peringatan dini banjir (flood early warning system/FEWS) di sepanjang Sungai Cileungsi dan Sungai Cikeas.

Berdasarkan analisis data tinggi muka air (TMA) yang telah terekam pada instrumen sistem peringatan dini banjir tersebut, dapat diperkirakan selang waktu yang dibutuhkan untuk memberikan peringatan dini kepada masyarakat Pondok Gede Permai. Dengan demikian diharapkan masyarakat memiliki waktu yang cukup untuk melakukan upaya evakuasi terhadap bencana banjir.

\subsection{Tujuan Penelitian}

Tujuan dari penelitian ini adalah menjelaskan tentang detil rancang bangun sistem peringatan dini banjir FEWS yang dibangun di DAS Bekasi bagian hulu khususnya disepanjang Sungai Cileungsi dan Sungai Cikeas. Data yang diperoleh secara empiris dan terekam pada instrumen tersebut akan digunakan untuk memprediksikan waktu yang dibutuhkan untuk memberikan sistem peringatan dini kepada masyarakat

\section{DATA DAN METODE}

\subsection{Data}

Data yang digunakan untuk analisis dalam penelitian ini menggunakan data historis hasil pengukuran tinggi muka air (TMA) sungai dan curah hujan yang telah terekam dalam basis data instrumen sistem peringatan dini banjir FEWS Kota Bekasi.

\subsection{Metode}

Rancang bangun sistem peringatan dini banjir FEWS yang dibangun di sepanjang Sungai Cileungsi dan Sungai Cikeas dijelaskan secara analitik deskriptif pada makalah ini. Data hasil pemantauan FEWS berupa tinggi muka air (TMA) dan curah hujan dianalisis untuk menentukan waktu yang dibutuhkan untuk memberikan peringatan dini.

Untuk menentukan waktu yang dibutuhkan untuk memberikan peringatan dini, maka perlu dilakukan pengukuran puncak tma air di stasiun hulu dengan puncak tma air di stasiun terdekat lokasi terdampak banjir. Perhitungan selang waktu dilakukan berdasarkan data empiris pengukuran pada saat terjadi hujan. Untuk itu digunakan data pengukuran pada tanggal 25 sampai dengan 26 Februari 2019 dan 3 sampai dengan 4 Maret 2019.

\section{HASIL DAN PEMBAHASAN}

\subsection{Konsep Sistem Peringatan Dini}

\subsubsection{Definisi}

Untuk menurunkan risiko atau kerugian akibat banjir yang terjadi di Pondok Gede Permai Kota Bekasi diperlukan adanya FEWS yang mampu memberikan peringatan kepada penduduk sebelum banjir terjadi, sehingga penduduk mempunyai kesempatan untuk bersiap-siap. Dengan adanya kesiapsiagaan di 
masyarakat, maka potensi kerugian bisa diturunkan. Sistem ini juga akan menjadi perangkat bagi pengelola wilayah untuk mengembangkan kecakapan dalam pengelolaan bencana khususnya banjir.

Peringatan dini didefinisikan sebagai "provision of timely and effective information, through identified institutions, that allows individuals exposed to a hazard to take action to avoid or reduce their risk and prepare for effective response" (UN/ISDR, 2004). Sedangkan menurut UU No. 24 tahun 2007 (ps. 46), peringatan dini dilakukan untuk pengambilan tindakan cepat dan tepat dalam rangka mengurangi risiko terkena bencana serta mempersiapkan tindakan tanggap darurat.

Jadi penekanannya adalah diperlukan kesiapan informasi bencana yang tepat waktu dan efektif, yang dikelola dan melewati institusi yang memang kompeten dan bertanggung jawab, agar masyarakat dapat mengambil tindakan yang dapat mengurangi risiko dirinya dari terkena kerugian yang mungkin ditimbulkan berdasarkan informasi bencana tersebut. Dengan demikian, sistem peringatan dini adalah upaya adaptasi terhadap suatu bahaya dimana kesiapsiagaan masyarakat atau pemerintah daerah menjadi elemen luarannya.

\subsubsection{Alur Data dan Informasi}

Alur data dan informasi sistem peringatan dini digambarkan pada Gambar 3.

\section{Sistem Peringatan Dini Banjir/FEWS} Berbasis SMS Gateway

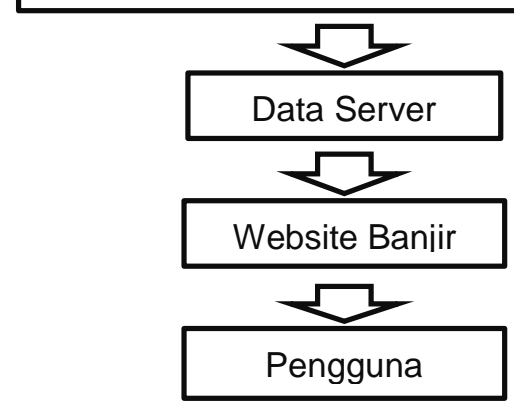

Gambar 3. Alur Data dan Informasi Sistem Peringatan Dini Banjir
Seluruh informasi yang diperoleh dari stasiun pemantauan di sungai dikumpulkan ke dalam server/pusat data melalui perangkat lunak sms-gateway, selanjutnya informasi tersebut akan didistribuskan ke beberapa pengguna data yaitu: BNPB, BPBD dan Komunitas Peduli Cileungsi Cikeas (KP2C) dan masyarakat melalui website.

Informasi ketinggian air akan digunakan sebagai penentu kondisi siaga bencana banjir yang akan dimanfaatkan untuk melakukan evakuasi bencana banjir, terutama informasi yang diperoleh dari Pos Bendung Irigasi Cibongas, Pos Cileungsi (Jembatan WIKA) dan Pos Cikeas (Warung Tape Uli) yang menjadi acuan utama dalam melakukan evakuasi di Pondok Gede Permai.

\subsubsection{Tipe Instrumentasi Pemantauan DAS}

\section{Kali Bekasi}

Desain peralatan instrumentasi pemantauan banjir di DAS Kali Bekasi terdiri dari tiga tipe yaitu :

a. FEWS untuk area hulu.

FEWS di hulu, hanya memiliki informasi tinggi muka air dan curah hujan saja. FEWS ini dibangun dengan menggunakan telemetri data menggunakan SMS, karena lokasi pemasangannya yang cenderung berada remote area yang tidak memiliki fasilitas 3G.

Informasi ketinggian air dan curah hujan yang terukur di stasiun pemantauan akan dikirimkan ke komputer server di pusat data dengan menggunakan SMS yang sekaligus juga berfungsi sebagai koordinator. Dari basis data, dilakukan pharsing data ke server website.

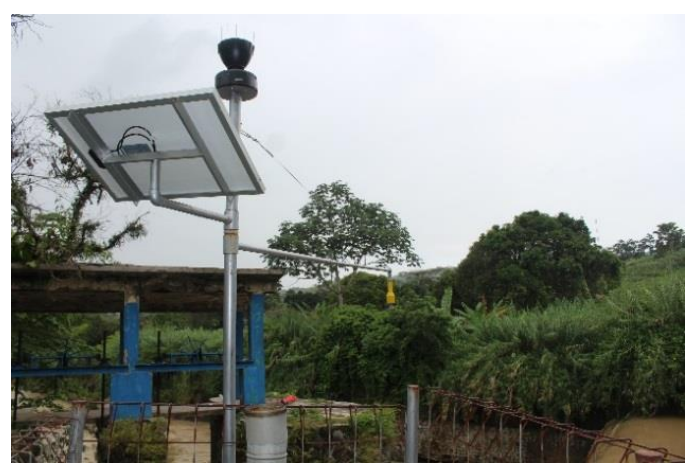


Gambar 4. FEWS untuk Wilayah Hulu Sungai Cileungsi Tanpa CCTV di Bendung Irigasi Cibongas

Kelebihan dari sistim SMS ini, alat bisa dimonitor dan dikendalikan secara langsung, karena perintah dapat dikirimkan langsung ke alat melalui data yang terkirim via SMS. Terdapat aplikasi yang dibangun dengan menggunakan perintah-perintah yang dapat dijawab oleh peralatan dan langsung ditampilkan dalam aplikasi tersebut. FEWS jenis ini terpasang di lokasi Sungai Cibongas dan Pesantren di Sungai Cileungsi.

b. FEWS antara di area tengah

FEWS antara dipasang di wilayah tengah sungai yang dapat menggunakan 3G. Peralatannya serupa dengan yang dipasang di hulu, akan tetapi dilengkapi dengan CCTV. Dengan menggunakan CCTV, maka selain tinggi muka air dari sensor, kita juga bisa melihat kondisinya secara visual. FEWS jenis ini terpasang di Jembatan WIKA (Sungai Cileungsi), Pos Tape Uli (Sungai Cikeas) dan Pondok Gede Permai (Pertemuan Sungai Cileungsi dan Cikeas).

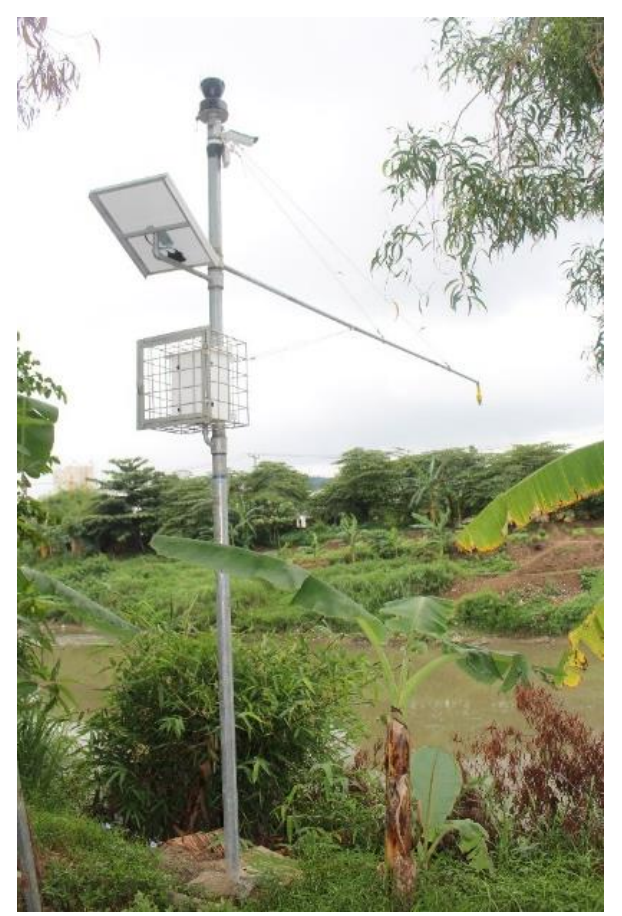

Gambar 5. FEWS dan CCTV untuk Wilayah Tengah Sungai

\subsubsection{Lokasi Pemasangan FEWS}

Nama lokasi, koordinat dan tipe FEWS yang terpasang di Sungai Cileungsi dan Cikeas diperlihatkan pada Tabel 1 berikut :

Tabel 1. Nama Lokasi, Koordinat dan Tipe FEWS di DAS Bekasi Hulu

\begin{tabular}{|c|c|c|c|}
\hline No. & $\begin{array}{l}\text { Nama } \\
\text { Lokasi }\end{array}$ & Tipe & $\begin{array}{c}\text { Lokasi } \\
\text { (Koordinat) }\end{array}$ \\
\hline \multirow[t]{2}{*}{1.} & \multirow{2}{*}{$\begin{array}{l}\text { Pondok } \\
\text { Gede Permai } \\
\text { (Pertemuan } \\
\text { Sungai } \\
\text { Cileungsi } \\
\text { dan Cikeas) }\end{array}$} & \multirow[t]{2}{*}{$\begin{array}{l}\text { FEWS + } \\
\text { CCTV }\end{array}$} & $\begin{array}{l}\text { S 061'13.99" } \\
\text { E 106 } 58^{\prime} 18.72 "\end{array}$ \\
\hline & & & 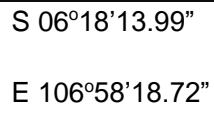 \\
\hline \multirow[t]{2}{*}{2.} & \multirow[t]{2}{*}{$\begin{array}{l}\text { Warung } \\
\text { Tape Uli } \\
\text { Sungai } \\
\text { Cikeas }\end{array}$} & \multirow[t]{2}{*}{$\begin{array}{l}\text { FEWS + } \\
\text { CCTV }\end{array}$} & $\begin{array}{l}\text { S 6 }{ }^{\circ} 22^{\prime} 21.70^{\prime \prime} \\
\text { E } 106^{\circ} 56^{\prime} 21.0\end{array}$ \\
\hline & & & 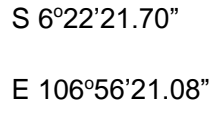 \\
\hline \multirow[t]{2}{*}{3.} & \multirow[t]{2}{*}{$\begin{array}{l}\text { Jembatan } \\
\text { WIKA Sungai } \\
\text { Cileungsi }\end{array}$} & \multirow[t]{2}{*}{$\begin{array}{l}\text { FEWS + } \\
\text { CCTV }\end{array}$} & $\begin{array}{l}\text { S 06²7'12.0" } \\
\text { E 106 } 55^{\circ} 27.1^{\prime \prime}\end{array}$ \\
\hline & & & $\begin{array}{l}\text { S 06 } 27^{\prime} 12.0^{\prime \prime} \\
\text { E 10655'27.1" }\end{array}$ \\
\hline 4. & $\begin{array}{l}\text { Bendung } \\
\text { Irigasi } \\
\text { Cibongas } \\
\text { Sungai } \\
\text { Cileungsi }\end{array}$ & FEWS & $\begin{array}{l}\text { S 6033'25.43" } \\
\text { E 106²5'8.55' }\end{array}$ \\
\hline 5. & $\begin{array}{l}\text { Pesantren } \\
\text { (Sungai } \\
\text { Cileungsi } \\
\text { Tengah) }\end{array}$ & FEWS & $\begin{array}{l}\text { S } 06^{\circ} 23^{\prime} 51.88 \\
\text { E 106² } 57^{\prime} 20.80^{\prime \prime}\end{array}$ \\
\hline
\end{tabular}




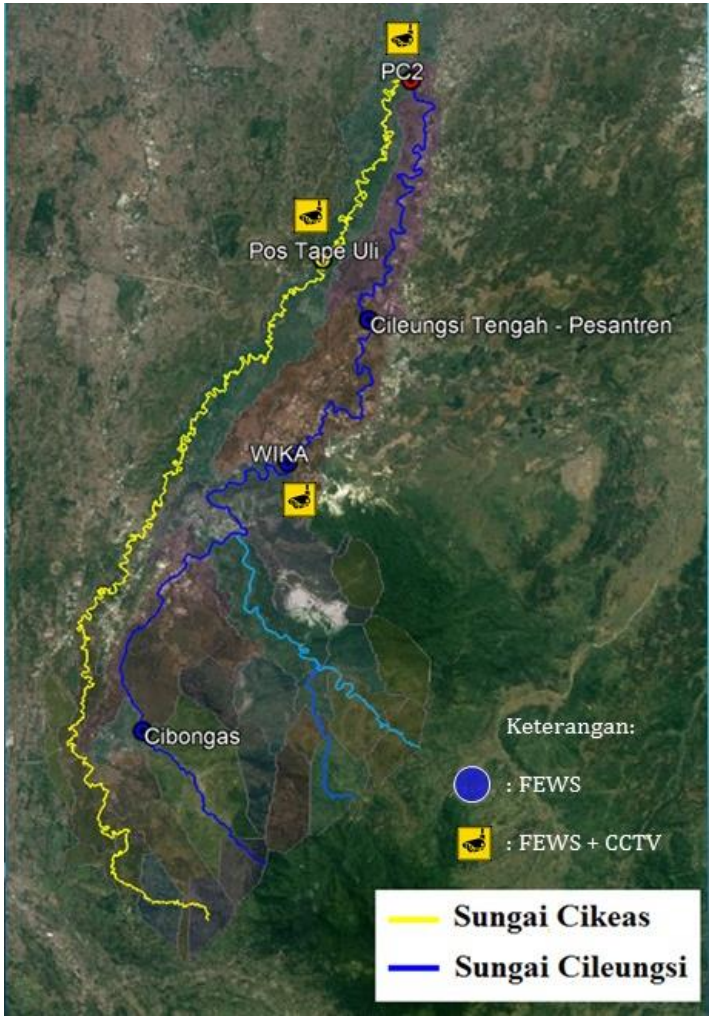

Gambar 6. Sebaran Lokasi FEWS di DAS Kali Bekasi Hulu di Sungai Clleungsi dan Cikeas

\subsubsection{Analisis Kebutuhan Waktu untuk Peringatan Dini}

Untuk memperkirakan waktu yang dibutuhkan untuk memberikan dini kepada masyarakat yang tinggal di Perumahan Pondok Gede Permai, maka perlu dihitung waktu yang tersedia

Secara empiris berdasarkan hasil analisis perbandingan data pengukuran tinggi muka air pada tanggal 25 Februari 2018, puncak tma di hulu (Sungai Cibongas) terukur pada pukul 17.00 WIB dan puncak tma hujan di hilir Sungai Cileungsi (Pondok Gede Permai) terdeteksi pada pukul 23.00 WIB sebagaimana diperlihatkan pada Gambar 8. Hal ini menunjukan bahwa selisih puncak tma di stasiun Cibongas akan sampai di Pondok Gede Permai selama 6 jam.

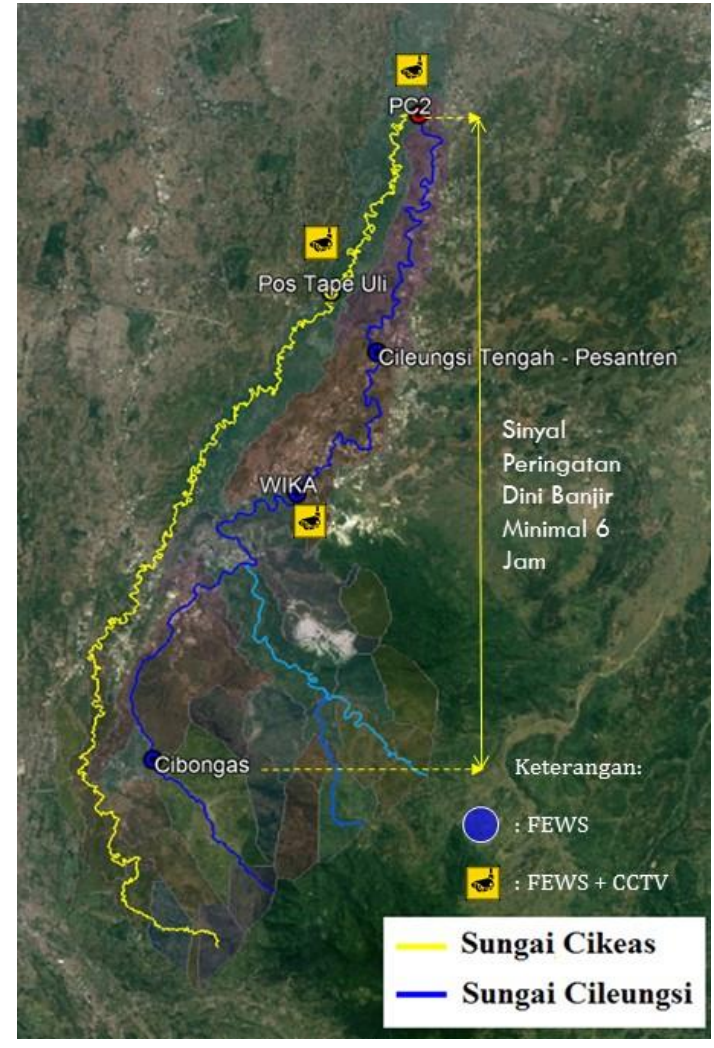

Gambar 7. Selang Waktu yang Dibutuhkan Untuk Peringatan Dini di DAS Bekasi Bagian Hulu

Pada tanggal 3 sampai dengan 4 Maret 2018 puncak tma di hulu (Sungai Cibongas) terukur pada pukul 19.30 WIB dan puncak tma hujan di hilir Sungai Cileungsi (Pondok Gede Permai) terdeteksi pada pukul 00.30 WIB. Dengan puncak TMA di stasiun Cibongas akan sampai di Pondok Gede Permai selama 5,5 jam.

TMA di stasiun WIKA Sungai Cileungsi tidak dapat terukur dengan baik pada tanggal 25 Februari maupun pada tanggal 3 s.d 4 Maret karena pada saat awal peningkatan tma hujan, hasil pengukuran tma dari sensor sonar mengalami penurunan akibat interferensi dari sensor sonar yang berada di dekatnya. Dengan demikian belum dapat dilakukan perhitungan selisih puncak tma dari Stasiun pemantauan Jembatan WIKA dan Stasiun pemantauan di Pertemuan Sungai Cileungsi dan Cikeas (PC2) di Pondok Gede Permai. 


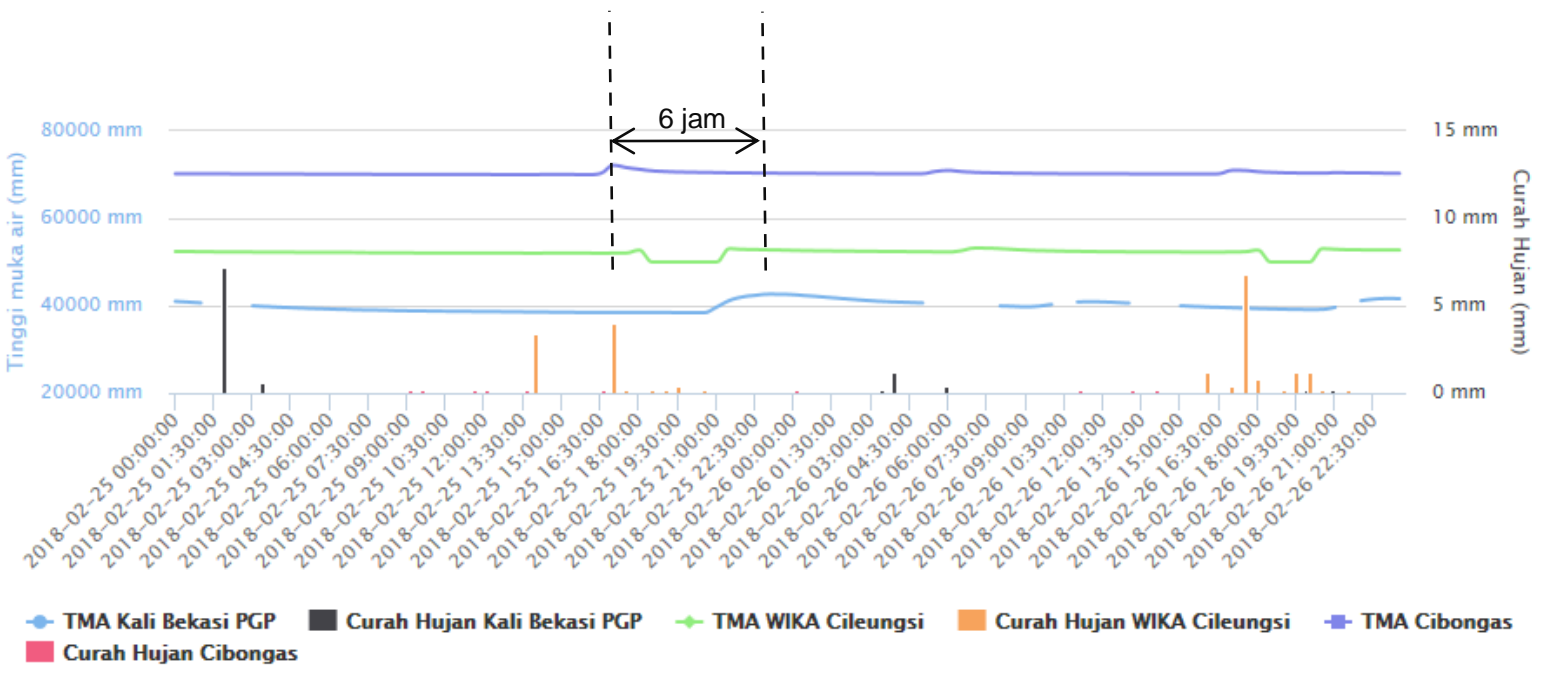

Gambar 8. Selang Waktu Puncak TMA Sungai Cibongas dan Pertemuan Sungai Cileungsi Cikeas di Pondok Gede Permai Bekasi Tanggal 25 sampai dengan 26 Februari 2018

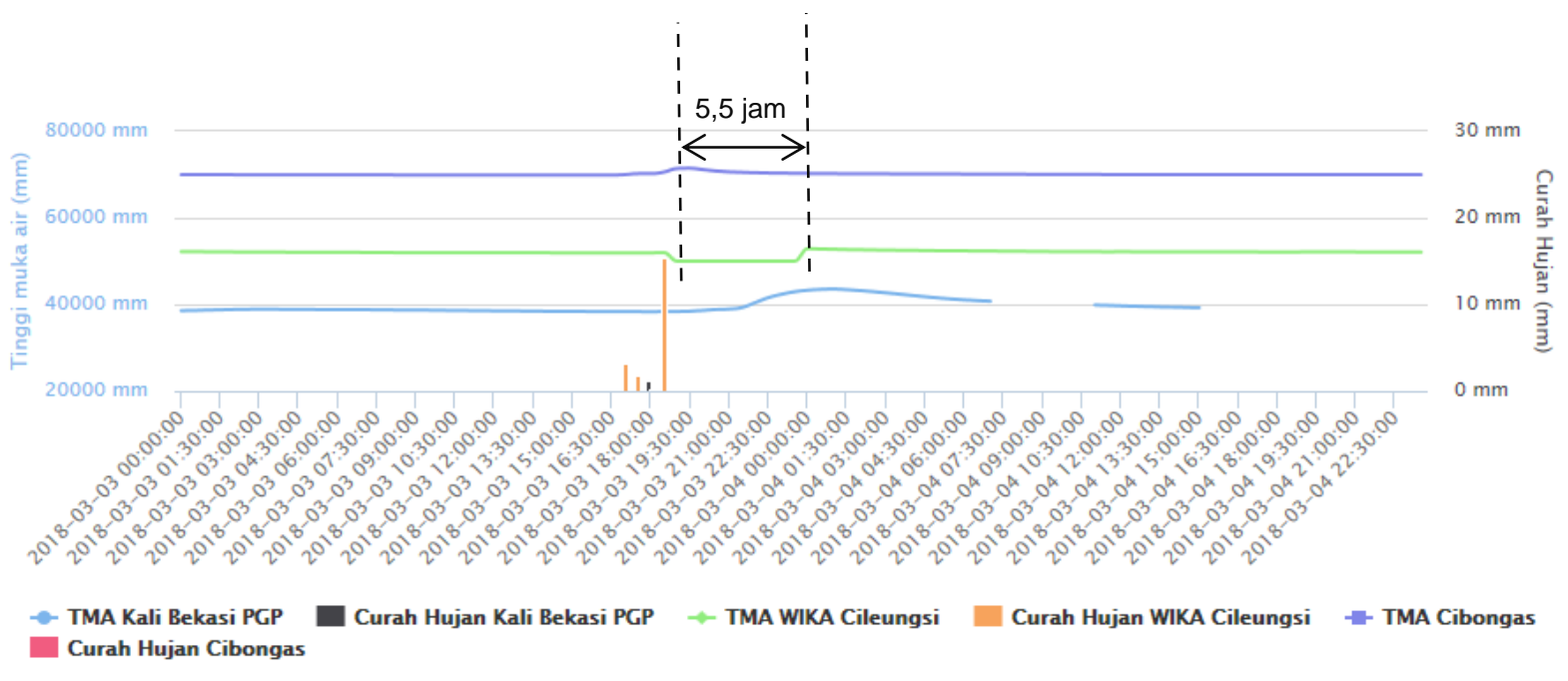

Gambar 9. Selang Waktu Puncak TMA Sungai Cibongas dan Pertemuan Sungai Cileungsi Cikeas di Pondok Gede Permai Bekasi Tanggal 3 sampai dengan 4 Maret 2018

\section{KESIMPULAN}

Sistem peringatan dini banjir yang dibangun di Sungai Cileungsi dan Cikeas mencatat tinggi muka yang dapat digunakan untuk memperkirakan waktu yang dibutuhkan untuk memberikan sistem peringatan dini kepada masyarakat.

Selisih puncak tinggi muka air di stasiun Cibongas dan puncak tinggi muka air di pertemuan sungai Cileungsi dan Cikeas dekat perumahan Pondok Gede Permai sebesar 6 jam. Selang waktu selama 5,5 - 6 jam antara Cibongas dan Pondok Gede Permai tersebut dapat dimanfaatkan untuk memberikan peringatan dini datangnya banjir kiriman dari hulu.

Data tinggi muka air di Stasiun Jembatan WIKA sungai Cileungsi pada saat penelitian ini tidak dapat digunakan untuk memberikan 
peringatan dini datangnya banjir kiriman karena sensor sonar yang digunakan mengalami interferensi dari sonar lain yang berada di dekatnya.

\section{PERSANTUNAN}

Ucapan terima kasih kami sampaikan kepada Badan Nasional Penanggulangan Bencana (BNPB), khususnya kepada Ir. Medi Herlianto, CES MM., yang pada saat pembangunan sistem peringatan dini banjir ini bertindak selaku Direktur Kesiapsiagaan. Ucapan terima kasih juga kami sampaikan kepada Ir. Eko Widi Santoso MS. sebagai Direktur PTRRB-BPPT. Penelitian ini merupakan bagian dari kerjasama penelitian antara PTRRB-BPPT, BNPB dan Badan Penanggulangan Bencana Daerah (BPBD) Kota Bekasi.

\section{DAFTAR PUSTAKA}

Bappeda. 2016. Rencana Pembangunan Jangka Menengah Kota Bekasi Tahun 2013-2018 Revisi http://bappeda. jabarprov.go.id/wp-content/uploads/2016/ 07/BAB-IIFINAL.pdf Rencana Pembangunan Jangka Menengah Kota Bekasi Tahun 2013-2018 Revisi

Nurhayati, M. 2009. Strategi Optimasi Daya Dukung Sumber Daya Air di Kota Bekasi, Tesis S2, PSIL Program Pasca Sarjana UI

Akhirianto, N. A. 2018. Pangetahuan dan Kesiapsiagaan Masyarakat terhadap Bencana Banjir di Kota Bekasi (Studi Kasus: Perumahan Pondok Gede Permai). Jurnal Alami, BPPT. Vol. 2, No. 1, Tahun 2018:63-72

Kadri, T., Sinukaban, N., Pawitan, H., Tarigan S. D., 2011. Analisis Penanggulangan Banjir Kota Bekasi dengan Pengelolaan DAS, Forum Pascasarjana, Vol. 34 No. 1 Januari 2011:1-11

Kadri, T. 2011. Analisis Penanggulangan Banjir Kota Bekasi dengan Pengelolaan DAS Bekasi Hulu. Sekolah Pasca Sarjana, IPB
Suparta. 2004. Kajian Banjir Kota Denpasar. Studi Kasus Saluran Drainase Sistem IV Kota Denpasar, Denpasar : Program Studi Magister Ilmu Ligkungan Program Pasca Sarjana, Universitas Udayana.

Undang-Undang Nomor 24 Tahun 2007 Tentang Penanggulangan Bencana

Hikmah, A. N. 2016. Evaluasi Implementasi Kebijakan dalam Penanggulangan Bencana Banjir (Studi Kasus di Kawasan Perumahan Pondok Gede Permai, Jatiasih, Kota Bekasi Perioder 2013-2014), Jurusan IImu Pemerintahan, Fakultas IImu Sosial dan IImu Politik, Undip.

Khairana, R.U. 2013. Kerentanan Banjir Di Bekasi, Departemen Geografi, FMIPA, Universitas Indonesia,

UNISDR. 2004. Priority Areas to Implement Disaster Risk Reduction "Building disaster resilient communities and nations", Helping to Set a New International Agenda. On-Line Conference https:// www.unisdr.org/2004/wcdr-dialogue/ terminology.htm 